\section{The Fragmented Inclusion of Gender Equality in AU-EU Relations in Times of Crises}

Political Studies Review

$1-16$ (C) The Author(s) 2020 (c) (i)

Article reuse guidelines: sagepub.com/journals-permissions DOI: 10.1 | $77 / 14789299209 \mid 8830$ journals.sagepub.com/home/psrev

@SAGE

\author{
Anna van der Vleuten' ${ }^{1}$ \\ and Anouka van Eerdewijk ${ }^{1,2}$
}

\begin{abstract}
Facing internal and external crises, the European Union and the African Union have revitalized their interregional cooperation. This article theorizes interregional norm dynamics and explores how, in times of crises, gender equality norms are shaped in interregional relations between the African Union and the European Union. The question is all the more relevant because gender equality is shaped very differently in the European Union and the African Union policies. The African Union has adopted a rather holistic understanding of gender equality, while the European Union approach is constrained by a market-making logic. Also, since the 2008 economic crisis, gender equality policies within the European Union seem to stagnate while they seem to expand in the African Union. Our analysis of core texts shows that at interregional level attention to gender equality is fragmented. Even though in some respects the African Union gender equality norms are more encompassing, and gendered effects of crises in the European Union would merit renewed attention to gender equality, the European Union norms and interests dominate the agenda. Showing how power asymmetries between and disjointed logics of regional organizations impact interregional gender equality norms, the article contributes to the scarce literature on interregional norm dynamics.
\end{abstract}

\title{
Keywords
}

African Union, crisis, European Union, gender equality, interregionalism, gender mainstreaming

Accepted: 23 March 2020

The relations between the African Union (AU) and the European Union (EU) are marked by the historical legacy of colonialism, a vast asymmetry in capacities and diverging interests. Unsurprisingly, crisis is always lurking in the background, easily fuelled by disagreements over issues such as migration, terrorism or financing of peacekeeping missions (International Crisis Group, 2017). Yet, despite mutual frustration, since 2017, the

\footnotetext{
'Institute for Management Research, Radboud University, Nijmegen, The Netherlands

${ }^{2}$ Royal Tropical Institute, Department of Sustainable Economic Development and Gender, Amsterdam, The Netherlands
}

\section{Corresponding author:}

Anna van der Vleuten, Institute for Management Research, Radboud University, PO Box $9108,6500 \mathrm{HK}$, Nijmegen, The Netherlands.

Email: a.vandervleuten@fm.ru.nl 
$\mathrm{AU}$ and the EU invest in interregionalism again. Their renewed interest is spurred by an awareness of their vulnerability in a changing world order and of their internal crises and weakness due to their inability to respond to major security and economic problems. These problems have gendered causes and consequences (see AU, 2019; Kantola and Lombardo, 2017). However, in the EU, since the outbreak of the financial crisis in 2008, gender equality policies seem to stagnate, while they have been further developed in the AU despite its internal crisis. AU and EU gender equality norms also seem to differ. Against this background, we ask how gender equality norms are (re)shaped in the relations between the AU and the EU?

Given the paucity of scholarly work on norm dynamics in interregional relations, this article aims to theorize interregional dynamics and their outcomes regarding gender equality norms by combining insights from scholarship on comparative regionalism, norm diffusion and feminist institutionalism. Our conceptual framework is grounded in the idea that regional organizations have a mission that produces a logic which structures their policies (Roggeband et al., 2014). The logic also shapes gender equality norms by enabling easier adoption of norms that fit this logic, compared to non-matching ones, and by facilitating or thwarting access for specific norm entrepreneurs. We argue that at interregional level, norm dynamics will be shaped by the logic underlying interregional cooperation, and the logics and power (a)symmetry of the regional organizations involved. Empirically the article is based on close reading of relevant $\mathrm{AU}$ and EU policy documents in order to unpack the gender equality norms they contain. After briefly introducing the AU, the EU, their respective missions and logics and their relations, we trace the content of gender equality norms in regional and interregional documents. The analysis shows that the AU has developed an encompassing gender equality framework, shaped and enabled by an underlying state-led developmental logic. The EU, in turn, has adopted strong gender equality norms, but these norms are narrowed down by a market-making logic. In its external relations, the EU is guided by a missionary logic based on its mission as 'ethical intervener' (Rutazibwa, 2010), which is disjointed from its trade policies based on a market-making logic. Interregional policy documents pay fragmented attention to gender equality as standalone norm, but they lack a cross-cutting approach and only address the need for change in Africa. This is explained by the dominant role of the EU, which reduces African actors to norm-takers and objects of change, and the intergovernmental character of interregionalism which hampers access for non-state actors.

\section{Interregionalism and Norm Dynamics - A Conceptual Framework}

Interregionalism is still a fragmented field of study despite the exponential growth of formal and informal relations between world regions since the 1990s (Ribeiro Hoffmann, 2016). Much attention has been devoted to definitional issues (Hänggi, 2006), but scholars will agree that AU-EU cooperation is an example of so-called 'pure interregionalism', understood as the politics and policymaking by 'two clearly identifiable regional organizations within an institutional framework' (Baert et al., 2014: 5). Scholarship on 'pure interregionalism' is mainly EU-centred. Arguably, this reflects how the EU was the first regional organization to promote regionalism in other world regions (Van der Vleuten and Ribeiro Hoffmann, 2013). As a result, some scholars have adopted an EU foreign policy approach (Hardacre and Smith, 2014) to investigate 
under which conditions EU external governance is effective, in the sense of successfully transferring its rules to third countries and organizations (Lavenex and Schimmelfennig, 2009). EU norms and its self-image as norm entrepreneur are taken as given. Hence, this approach seems unfit for dealing with our research question, as it is unable to address interregional norm dynamics as a two-way process in which the content of norms is not fixed but renegotiated time and again between both actors. Less EU-centred approaches from International Relations and International Political Economy (for an overview, see Ribeiro Hoffmann, 2016), which aim to explain stagnation or progress of interregional cooperation, are not helpful for understanding how norms are shaped as part of cooperation, either.

We hence draw on comparative regionalism, to allow us to zoom in on norm dynamics in (inter-)regional governance without 'being trapped in either parochialism or misplaced universalism (usually Eurocentrism)' (Söderbaum, 2016: 33). Amitav Acharya (2016), pursuing a non-EU-centric perspective, points out that regionalism in the nonWestern world is driven by a quest for autonomy, inspired by anti-colonialism, national liberation and protection of sovereignty; this is unlike the European emphasis on integration and the taming of nationalism by supranational institutions. Consequently, regional governance has developed differently in non-EU and EU institutional settings. The subsequent question how interregional governance between fundamentally different regional organizations develops has hardly been addressed yet. Building on Risse (2016), we assume that norm dynamics at the regional level will influence norm dynamics at the interregional level. These multilevel processes are driven by actor constellations of norm entrepreneurs and norm antipreneurs that promote and resist normative change, respectively (Bloomfield, 2016). We assume that actors are enabled and constrained by the institutional landscape in which they promote and negotiate their interests, and more particularly by its underlying logic.

The concept of 'logic' needs some elaboration. Upon their creation, regional organizations are endowed with a mission, and in this respect they differ fundamentally from functional international organizations. The latter focus on a specific policy domain, such as health, agriculture or trade, in which they aim to improve global policymaking; while the former are grounded in a (constructed) territorial and cultural entity, with a mission that binds and drives its member states. This mission constructs the regional organization and produces a logic as an underlying mode of reasoning structuring its institutions and policies (Roggeband et al., 2014). The logic of regional governance also shapes gender equality norms in specific ways, because in order to be successful, norm entrepreneurs will frame norms in such a way that they resonate with the logic. Shaping the regional institutional arena, the logic will facilitate or thwart access for norm entrepreneurs and antipreneurs, empowering or weakening them selectively.

Moving to the interregional level, we notice how mission and institutionalization of interregional cooperation are rather thin compared to the regional level. Interregionalism tends to be purely intergovernmental, with decision-making based on consensus between member state representatives and enforcement depending on voluntary peer review mechanisms (Ribeiro Hoffmann, 2016). As a result, interregionalism lacks agency independently from the regional organizations involved. Therefore, one could argue that interregionalism simply reflects the norms promoted within the regional organizations involved. However, this would ignore the ways in which interregional institutions, rules and practices not only reflect but also constrain and enable interactions and outcomes. We understand interregionalism as an arena which is shaped by the mission of interregional 
cooperation. This mission will be of a thin, more functional nature, although it will be grounded in references to a shared culture and history. The processes and outcomes of interregional norm dynamics will hence be shaped by, first, the thin logic underlying interregionalism and, second, the logics of and power (a)symmetry between the regional organizations involved. Matching (inter)regional logics may be expected to result in consistent norms, while contrasting or disjointed (inter)regional logics can be expected to result in uneven norm dynamics and fragmented and often weak norms which reflect the logic of the more powerful regional organization.

\section{A Note on Method}

Given the dearth of scholarly work on interregional norm dynamics, the empirical sections have an exploratory character and offer a plausibility probe for our conceptualization, based on desk research of primary and secondary sources. Also, although we want to understand how gender equality norms fare in times of crisis, we are unable to say whether crisis has resulted in a certain type of policy change (see Hall, 1993). The identification of policy change would require a clear timing of crisis, but in AU-EU relations we cannot determine a before/after. In Africa, crises characteristically are of protracted nature, such as climate change, food insecurity, state breakdown, warlordism and terrorist violence, all connected and aggravating each other, without a clear starting year. They provoke intra-African migration, which fluctuates depending on the severity of violence and food insecurity, and migration towards Europe. The AU also struggles with a protracted institutional crisis, as it lacks financial autonomy, institutional capacity and focus (International Crisis Group, 2017). For the EU, usually 2008 is taken as the year in which the crisis started when banks failed and domino effects rippled through the economy. Austerity measures, the failure to deal with high numbers of migrants, and a series of terrorist attacks generated the feeling that the EU was unfit to protect its citizens' interests. It fuelled Eurosceptic radical right and left populism, and a deep legitimacy crisis ensued, exemplified by the UK decision to leave the EU. Summarizing, over the past decade, the AU and the EU have experienced multiple crises which differ in timing, topic and impact. We do not identify policy change due to crises, but look at ways in which crisis is referred to in relation to gender equality norms.

We have selected key regional and interregional strategy documents, which reflect the (inter)regional mission and steer further policy development, as well as key documents about gender equality (see Table 1).

We operationalize the mission as the core aim of each organization, articulated in their founding documents, and derive a logic depending on its market- or state-empowering nature (Van der Vleuten, 2016). We have included documents from interregional nonstate actors, in order to assess to what extent their ideas are adopted in intergovernmental documents. Close reading enables us to explore which understanding of gender equality features in documents. We distinguish gender equality as cross-cutting norm (gender mainstreaming) and stand-alone norm. For the latter we identify three forms, broadly speaking. First, a gender equality norm may refer to gendered practices and impacts for both women and men. Second, it may focus on women as agents of change, who have rights and are empowered. Third, it may refer to women as a specific category, as objects of change which should adapt to the dominant standard. Before turning to gender equality in interregional relations, the next section first offers a brief discussion of AU and EU regionalism and interregionalism. 
Table I. Overview of Documents Analysed (Bold: Specific Gender).

\begin{tabular}{|c|c|c|}
\hline African Union & European Union & AU-EU \\
\hline $\begin{array}{l}\text { AU Constitutive Act (2000) } \\
\text { NEPAD (2002) }\end{array}$ & $\begin{array}{l}\text { Treaty of Amsterdam } \\
\text { (1997) }\end{array}$ & $\begin{array}{l}\text { Joint Africa-EU Strategy (JAES) } \\
(2007)\end{array}$ \\
\hline $\begin{array}{l}\text { AU Maputo protocol (2003) } \\
\text { Solemn Declaration on }\end{array}$ & $\begin{array}{l}\text { Strategic Commitment } \\
\text { to Gender Equality } \\
(2015)\end{array}$ & $\begin{array}{l}\text { Valletta Summit Political } \\
\text { Declaration }(2015)\end{array}$ \\
\hline $\begin{array}{l}\text { Gender Equality in Africa } \\
\text { (SDGE) (2004) }\end{array}$ & $\begin{array}{l}\text { Transforming Women } \\
\text { and Girls' Lives (GAP }\end{array}$ & $\begin{array}{l}\text { Renewed Impetus of the } \\
\text { Africa-EU Partnership (2017) }\end{array}$ \\
\hline $\begin{array}{l}\text { Agenda 2063: The Africa We } \\
\text { Want (2013) }\end{array}$ & II) $(2015)$ & $\begin{array}{l}\text { Africa-EU Civil Society Forum } \\
\text { Declaration (2017) }\end{array}$ \\
\hline $\begin{array}{l}\text { Gender Equality, Women's } \\
\text { Empowerment Strategy } \\
\text { (GEWE) (2019) }\end{array}$ & Future of Europe (2017) & $\begin{array}{l}\text { The Abidjan Declaration. 4th } \\
\text { Africa-Europe Youth Summit } \\
\text { (2017) }\end{array}$ \\
\hline
\end{tabular}

Abidjan Declaration (2017)

\section{African and European (Inter)Regionalisms}

Both AU and EU were created with aims to prevent war and promote prosperity. On the European continent, after two World Wars, key was the awareness that stability and prosperity required Franco-German reconciliation. With that objective, governments reluctantly agreed with the Schuman Plan to delegate competences to a supranational institution to oversee the production of coal and steel, as first step towards a customs union and, in the late 1980s, a common market (Lieshout, 1999). Based on its mission to prevent war by integrating markets, we characterize the logic of EU governance as market-making: it aims to eliminate obstacles to unfair competition and remove barriers to free movement of goods, services, capital and people. On the African continent, integration had to come to terms with the legacy of 'four centuries of slavery and another century of colonialism' (De Melo, 2017: first page), resulting in highly heterogeneous states and artificial state boundaries and, after independence, the 'proxy wars waged by the super powers and the ongoing adventures of the French gendarme' (Adebajo, 2012: 51). States were unwilling to relinquish freshly-won sovereignty, and the Organization of African Unity (OAU), established in 1963, remained purely intergovernmental. It was driven by pan-Africanism, anti-colonialism and anti-apartheid. When in 1994 apartheid in South Africa was abolished, the 'glue that held the OAU together' disappeared (Adebajo, 2012: 53). Confronted with growing poverty and continued insecurity, a renewed commitment developed to find African solutions to African problems and establish a Pax Africana through the creation of the AU in 2000. The AU aims at state- and community-building. Given its mission to achieve unity and solidarity among the peoples of Africa and African States and to enable Africa to 'play its rightful role' in the global economy and international politics (AU, 2000: Article 3i), we characterize its logic as state-led developmental (Van der Vleuten, 2016).

The different historical legacies of the AU and EU are visible in their institutional design. At first sight, institutions look highly similar, with a Commission, an AU Assembly of Heads of State (European Council), an AU Executive Council (Council of the EU), a parliament and a court. However, they differ strongly in their capacity to act. Like its predecessor, the AU is intergovernmental, Heads of State-driven. The AU Assembly of Heads of State is the highest decision-making body. The AU Commission 
has the mandate to initiate proposals but lacks resources and staff to do so effectively. The Pan-African Parliament is based in South Africa, far away from the Commission and the Assembly in Ethiopia, and lacks staff, funding and a clear mandate. Overall, the AU lacks financial autonomy: $60 \%$ of the budget is provided by external parties, mainly China, the EU and the United States (Adebajo, 2012: 66). EU institutions, in comparison, are well-funded, based on import duties, sugar levies, value added tax, fines for non-compliance, and member states' contributions. The European Commission has an exclusive right to draft new legislation, and in most domains the supranational European Parliament has co-decision powers with the intergovernmental Council of the EU. These different institutional designs seamlessly fit Acharya's (2016) aforementioned characterization of non-Western and Western integration.

In 2000, a first summit took place of the OAU/AU and EU in Cairo. Until then, cooperation had mainly developed at subcontinental level in trade and development agreements between EU and former colonies. In Cairo, a new type of continent-to-continent political relationship emerged (Kotsopolous and Mattheis, 2018). At a second summit, in 2007, it found a formal basis with the adoption of the Joint Africa-EU Strategy (JAES). The JAES (AU-EU, 2007: 2) formulated the mission of AU-EU interregionalism as 'to bridge the development divide between Africa and Europe through the strengthening of economic cooperation and the promotion of sustainable development in both continents', a mission with a developmental logic. AU-EU cooperation has developed since through triennial summits involving the heads of state and government, and annual meetings of the EU and AU Commissions and of foreign affairs ministers. Other meetings, such as preparatory or side events to the summit, bring together the two regional parliaments, youth, business, civil society or subnational authorities.

Despite the commitment of the JAES, over time, AU-EU relations have 'ebbed and flowed' (Kotsopolous and Mattheis, 2018: 451). Most recently, critical moments in AU-EU relations occurred in 2015 over migration and in 2016 over financing of peacekeepers. Brexit will impact AU-EU relations as well, because the United Kingdom used to be one of the drivers of EU engagement with Africa. More in general, the EU resents being perceived as a cash machine and is frustrated over the incapacity of the AU to deliver, while the AU resents being patronized by the EU and complains about the lack of reciprocity in their relations (International Crisis Group, 2017; Rutazibwa, 2010). Summits address African issues and never European ones, the AU is not invited to relevant EU meetings in Brussels although EU is invited to Addis Ababa, and the EU does not follow the AU in dealing with crises in Africa but takes the lead (International Crisis Group, 2017; Rutazibwa, 2010). Against this background, how have gender equality norms developed?

\section{Gender Equality Norms in the AU}

The state- and community-building mission of the AU would allow for accommodating gender equality as cross-cutting and as stand-alone norm aimed at empowering women. Indeed, from the start, AU core documents refer to gender as a source of structural inequality. Its Constitutive Act enshrines the promotion of gender equality as one of 16 basic principles (AU, 2000). In 2002, the AU adopted the New Partnership for Africa's Development (NEPAD), a strategic framework for socioeconomic development. Its objective was 'to eradicate poverty, place African countries on a path of sustainable growth and development, halt marginalisation of Africa in the globalisation process, accelerate the empowerment of women and fully integrate Africa into the global 
economy' (AU, n.d.: 1). In 2003, the AU member states adopted a specific document on gender equality, the Protocol to the African Charter on Human and Peoples' Rights on the Rights of Women in Africa, widely referred to as 'the Maputo Protocol'.

The adoption of the Maputo Protocol was a landmark decision for the AU. It is a comprehensive framework combining cross-cutting and stand-alone gender equality norms (AU, 2003). It defends women's rights to participation in political and decision-making processes, in law enforcement and the judiciary, and in the promotion and maintenance of peace. It promotes women's rights with respect to land, property and inheritance. It recognizes the right to protection in armed conflicts, with specific reference to women asylum seekers, refugees, returnees and displaced persons, and to legal protection against gender-based violence in public and private spheres, and in times of peace and war. It is progressive in regard to HIV and AIDS, child marriage, harmful practices (female genital mutilation) and access to safe abortion (on specific grounds) (Banda, 2005; Van Eerdewijk and Lodenstein, 2018). In 2004, the AU reaffirmed its commitment to gender equality by the adoption of a Solemn Declaration on Gender Equality in Africa; it underlines the gender parity principle adopted to promote women's representation in politics and political decision-making.

In 2015, after the Golden Jubilee celebrations of the formation of the OAU, the AU adopted 'Agenda 2063: The Africa We Want'. It is an ambitious blueprint that aims to 'Galvanize and unite in action all Africans and the Diaspora', and 'Harness the continental endowments embodied in its people, history, cultures and natural resources, geopolitical position to effect equitable and people-centred growth and development' (AU, 2015: 2). It stresses the importance of state sovereignty and the focus on people-driven development. Agenda 2063 aims to realize gender equality 'in all spheres of life' (Aspiration 6), while prioritizing women empowerment and fighting violence and discrimination against women (AU, 2015: 9). Most recently, in February 2019, the AU launched the Strategy for Gender Equality and Women's Empowerment (GEWE) 2018-2028. It seeks to implement Aspiration 6 of Agenda 2063. Many African civil society organizations (CSOs) have contributed to the strategy, including feminist organizations, faith-based organizations, women farmer organizations and academics (AU, 2019: 66-67). The GEWE Strategy consists of four pillars: (1) Maximizing (economic) Outcomes, Opportunities and Tech E dividends; (2) Dignity, Security and Resilience; (3) Effective Laws, Policies and Institutions; and (4) Leadership, Voice and Visibility. Violence against women and Women, Peace and Security are prominent under pillar two, together with sexual and reproductive health and rights. Domestication and implementation of the Maputo Protocol is a key objective under the third pillar. The GEWE Strategy also is the first AU document that refers to sexual orientation, hidden in the definition of Sexual and Reproductive Health and Rights that 'can be understood as the right for all, whether young or old, women, men or transgender, straight, gay, lesbian or bisexual, HIV positive or negative, to make choices regarding their own sexuality and reproduction' (AU, 2019: 65). Migrant women are one of five target groups of the GEWE Strategy, because 'Recent years have witnessed larger numbers of women on the roads of migration, often forced to leave their homes due to conflict or economic circumstances' (AU, 2019: 14). Men and boys are also highlighted as one of the target groups, pointing at their role in contributing to gender equality. To sum up, the documents show how the AU combines cross-cutting and stand-alone norms on gender equality. Its holistic approach resonates with the state-led developmental logic of community-building and people's oriented regional integration. 


\section{Gender Equality Norms in the EU}

EU governance is shaped by a market-making logic, and gender equality policies have been developed and justified in terms of this logic as fighting discrimination and empowering women in the labour market (for recent overviews of EU gender equality policies, see Abels and Mushaben, 2012; Debusscher and Van der Vleuten, 2017; Jacquot, 2015). In the 1990s, facing enlargement with vulnerable democracies after the fall of the Berlin Wall, the EU embraced a second mission, namely to fight totalitarianism and promote human rights, good governance and democracy. This mission of 'ethical intervener' (Rutazibwa, 2010: 215) was codified in the Treaty of Amsterdam (1997) and enabled an approach to gender equality as human rights beyond the labour market. The Treaty of Amsterdam, moreover, stipulated that 'In all the activities . . ., the Community shall aim to eliminate inequalities, and to promote equality, between men and women', known as the gender mainstreaming obligation (Article 3, now Article 8 Treaty on the Functioning of the EU).

Since 2008, EU 'internal' gender equality policies have faced stagnation and even dismantling (Jacquot, 2015), as is reflected by the lack of ambition characterizing the Strategic Engagement for Gender Equality 2016-2019 (European Commission, 2015b). The European Commission mainly reiterates aims from previous strategies to strengthen women's position in the labour market and reduce gender pay and pension gaps. It also presents measures to promote women's role in decision-making in companies and politics, and to combat gender-based violence, but it has only weak, soft-law instruments at its disposal for issues which are not market-oriented. In 2017, acknowledging the impact of the economic, migration and legitimacy crises, the European Commission (2017d) presented a proposal for renewing the EU offering 'Reflections and scenarios for the EU27 by $2025^{\prime}$. The few gender equality norms it contains reflect a market-making logic, arguing that women are talents whose potential should be better mobilized to keep the economy afloat (Ahrens and Van der Vleuten, 2019). Overall, the scenarios are predominately gender-blind (Walby, 2018), confirming Galligan (2017) who finds that a gender perspective 'flows in and out' of EU politics depending on the push by feminist actors and institutional power plays that undergird gender equality's policy salience. Apparently, gender equality is perceived as unrelated to crisis policymaking.

In its external relations, the EU claims to be 'at the forefront of the protection and fulfilment of girls' and women's rights' (European Commission, 2015a: 2). This mission is elaborated in the framework called 'Gender Equality and Women's Empowerment: Transforming the Lives of Girls and Women through EU External Relations 2016-2020' (GAP II). GAP II has three central pillars: to fight violence of any kind against women and girls and empower women to have control over their sexual and reproductive life; to increase access of women and girls to education, capital, jobs and basic services; and to strengthen women's participation in policymaking and decision-making. GAP II stands out because of its attention to empowerment and giving voice to women and girls. It explicitly acknowledges how 'the gender gap is even larger when gender inequality intersects with other forms of exclusion such as disability, age, caste, ethnicity, sexual orientation, geographical remoteness or religion' (European Commission, 2015a: 3). Its set of measurable targets for 2020 makes it results-oriented. Unfortunately, GAP II hardly pays attention to trade, although the EU is first and foremost a trade power ('Market Power Europe', see Damro, 2012). Strikingly, although it points to the need of attuning EU activities to local needs, it does not once refer to the Maputo Protocol or other documents from actors in the Global South. 
GAP II priorities are echoed in the broader EU strategy on external relations which was proclaimed on 25 June 2016, 2 days after the resounding 'no' of the Brexit referendum. The Global Strategy for the European Union's Foreign And Security Policy promises that 'we will systematically mainstream human rights and gender issues' and acknowledges that the European External Action Service and the Commission need 'greater awareness and expertise on such issues' (EEAS, 2016: 51). The EU will develop 'more creative approaches to diplomacy' by promoting the role of women in peace efforts and 'having more systematic recourse to cultural, inter-faith, scientific and economic diplomacy in conflict settings' (EEAS, 2016: 31). Relevant to EU-AU relations is the section on 'Resilience in our surrounding regions', where the EU promises to fight 'poverty and inequality [. . .] and champion decent work opportunities, notably for women and youth', focusing specifically on origin and transit countries of migrants and refugees (EEAS, 2016: 26).

All in all, EU gender equality norms internally and externally are disjointed. The former are shaped by a market-making logic and are characterized by stagnation, while the latter are shaped by a missionary, human rights-oriented logic and show more ambition, including gender equality as cross-cutting norm, although they risk to remain confined in development policies (Allwood, 2019). In the next section, we explore how this plays out in EU-AU interregionalism.

\section{Gender Equality Norms in AU-EU Interregionalism}

In the interregional, AU-EU arena, the JAES was the first strategy document, a comprehensive agreement which aims to address common challenges in the fields of peace and security, migration, development and environment. Reflecting the AU mission, it aims to be 'people-centred' by empowering non-state actors, comprising private sector, economic and social partners, and civil society (AU-EU, 2007: 3). The JAES is remarkable for its awareness of colonial patterns of inequality and its commitment to prevent reproducing them. It frequently stresses how the AU-EU partnership 'will be based on a Euro-African consensus on values, common interests and common strategic objectives' (AU-EU, 2007: 2 ) and calls, for instance, for fighting mutual stereotypes. Gender equality figures in the sections on human security and governance. In addition, the JAES promises to promote sexual and reproductive health and rights, and to address 'the entire range of women's rights and [. . .] to fight the feminisation of poverty, to promote women in decisionmaking positions and peace processes, and fight sexual and gender based violence against women' (AU-EU, 2007: 14). Last but not least, 'Africa and the EU will also strengthen the inter-institutional fabric of their administrations to mainstream gender equality in all strategies, policies, programmes and actions' (AU-EU, 2007: 14). Given this commitment to gender mainstreaming and the references to gender equality and women's rights in several sections, the JAES can be considered to have a comprehensive approach which transcends a market-making logic and resonates with a developmental logic. Close reading, however, reveals some shortcomings. In sharp contrast to other sections, the section on trade does not refer to gender equality or gendered impacts. Also, despite efforts to avoid asymmetrical patterns, there is an imbalance between AU and EU obligations. The section on gender mainstreaming refers to the United Nations Beijing Platform for Action and the AU Solemn Declaration on Gender Equality, but lacks reference to EU treaty obligations (AU-EU, 2007: 14). What misses altogether is a recognition that the EU could learn from the AU, for instance as regards the holistic approach to women's rights in the Maputo Protocol or the aim of gender parity in the Solemn Declaration. 
As a follow-up to the JAES, two action plans and a roadmap were adopted. However, discontent on AU-EU relations simmered. We highlight four sources of disagreement which are relevant to gender equality as well. First, despite the people-centred aim of the JAES, African and European CSOs did not play the role they had anticipated in holding political dialogues and monitoring the agreement. Worse, they felt 'increasingly marginalized' (European Parliament, 2017: 16). Second, the issue of human rights has raised controversies. Both AU and EU emphasize their importance, but they disagree on the rights of lesbian, gay and trans people. Also, EU programmes in Africa focus on civil and political rights, while the AU prioritizes socioeconomic rights such as access to food, water and sanitation and argues these are attuned to African needs (Miyandazi et al., 2018). A third controversy regards migration. While the AU talks about labour mobility and perceives migration as an opportunity 'to foster development and integration within the continent' (Miyandazi et al., 2018: 471), public opinion and governments in the EU perceive migration as a threat and link it to terrorism. Fourth, and underlying all feelings of annoyance, the partnership is perceived to be dominated by the EU agenda. While the EU criticizes human rights violations in Africa, the AU complains about the inconsistency between the so-called 'value-based foreign policy' of the EU and its pursuit of specific security interests (European Parliament, 2017). In vain the AU tries to put human rights violations of African migrants by the EU on the agenda, which 'has reinforced the African perception of a one-way dialogue, ultimately aimed at imposing EU conditionality on its counterpart' (European Parliament, 2017: 18). This perception was further reinforced at the AU-EU summit dedicated to migration in Valletta, Malta, in November 2015. African demands for opening paths for legal migration were put on a backburner, while EU prioritized sealing its borders, investing in projects promoting return of migrants to countries of origin and strengthening border security within Africa. These policies, however, undermine intra-African mobility and may have a negative impact on development (Miyandazi et al., 2018). As regards gender equality, promisingly, in the Political Declaration of the Valletta summit, African and European leaders 'commit to undertake concrete actions to respond to challenges of migration and mobility at the appropriate level and with a gender perspective' (Council, 2015a: 3, italics added). In the accompanying Action Plan, however, this cross-cutting gender norm is shrunk to the vague promise 'to pay attention to the gender of victims of trafficking' (Council, 2015b: 3) and to support 'the most vulnerable, in particular women and children' (Council, 2015b: 12), reflecting a narrow 'women-and-children' approach (Welfens, 2019).

In 2016, interregional relations reached a nadir over EU payments to the AU mission in Somalia (International Crisis Group, 2017), while AU and EU were each struggling with a legitimacy crisis. Given the pressing need to tackle joint challenges such as migration, terrorist violence and climate change, they decided to reassess their cooperation (European Commission, 2017b, 2017c). In May 2017, the assessment resulted in a text entitled Renewed Impetus for the Africa-EU partnership (European Commission, 2017a). The document, drafted by the European Commission, reads as an 'EU wish list for the next Summit' (European Parliament, 2017: 31). 'The actions rarely seem to be oriented toward real reciprocity' (European Parliament, 2017: 34); for instance, proposals on migration are mainly aimed at reducing migration towards Europe and do not address intra-African migration, and the allocation of aid is aligned with migration patterns instead of African priorities. As regards gender equality, the Renewed Impetus is meagre. In the section on responsive governance, the document refers to women's empowerment without proposing any concrete measures. Taking an 'adding-women' approach, it refers 
to access to education for girls, capacity-building projects promoting women and young peoples' active participation in society and the economy, and developing digital skills of entrepreneurs including women (European Commission, 2017a: 22). Finally, none of the key proposals, called Flagships, has a gender equality-related objective. In its critical study of the Renewed Impetus, the European Parliament (2017) does not adopt a gender perspective either. Just as a suggestion for further action, it proposes to establish networks of European and African women. Interestingly and surprisingly, the Council of EU Foreign Affairs Ministers adopted Conclusions based on the Renewed Impetus which contain two strong sections on gender equality (Council, 2017). First, the aim of promoting resilient societies is connected to promoting inclusive societies with equality between women and men and equal participation in decision-making, and with continued efforts to eliminate gender-based violence. Second, it reaffirms EU's commitment to 'the full and effective implementation of the Beijing Platform for Action' and to 'the promotion, protection and fulfilment of the right of every individual to have full control over, and decide freely and responsibly on matters related to their sexuality and sexual and reproductive health' (Council, 2017: 6). In addition, it refers to women's and/or girls' needs in sections on education, peace and security, and employment. The short Council document hence offers more substantial attention to gender equality than the Renewed Impetus. It resonates with the EU missionary logic.

Interregional non-state actors also have formulated demands for the 2017 triennial AU-EU Summit. African and European CSOs met in Tunis from 11 to 13 July 2017 for the 4th Africa-EU Civil Society Forum. They adopted a Declaration which, unsurprisingly, regrets that despite repeated calls for action, the space for civil society has shrunk, the Joint Annual Forum for CSOs was never convened and promises in the JAES have not been followed through. They demand an 'inclusive multi-stakeholder policy process' (Africa-EU Civil Society Forum, 2017: 2). The Declaration builds on Agenda 2063 and the Renewed Impetus. It is aimed at change in Africa only, which does not come as a surprise given the composition of the Forum of European humanitarian assistance and development CSOs and African development CSOs, and it is strong on gender. The Declaration recommends to 'promote gender equality as a stand-alone and cross-cutting priority and mainstream it throughout human development' (Africa-EU Civil Society Forum, 2017: 4). It presents 45 recommendations under five headings: Conflict Prevention, Peacebuilding and Refugees; Democratic Governance; Human Development; Decent Work; and a Sustainable Future for Our Planet. Gender equality is a cross-cutting issue, along with migration and mobility, and youth. As a result, each section includes specific recommendations concerning these issues.

In October 2017, also representatives from youth organizations in Africa, Europe and the African diaspora in Europe met for the 4th Africa-EU Youth Summit in Abidjan. They adopted a Declaration with recommendations to improve the position of young people, including young migrants, in education, entrepreneurship, sustainable agriculture, governance, culture and arts. The Declaration contains a single mention of gender, when calling upon the EU and AU 'to tackle racism and discrimination in all forms, including that based on gender, ethnicity, religion, culture and geographical location' (AfricaEurope Youth Summit, 2017: 7). In the follow-up documents which youth organizations developed, gender equality is one of three cross-cutting issues, with migration and digitalization. Interestingly, the Declaration is the first document to address both AU and EU as agents as well as objects of change, which follows from its truly interregional aim to promote the interests of young people on both continents. 
As a follow-up to all preparatory efforts, the 5th AU-EU summit took place in Abidjan on 29-30 November 2017. The agreed theme was 'youth', in accordance with the AU theme of the year: 'Harnessing the Demographic Dividend Through Investments in the Youth' (Aldiplomasy, 2017). 'Youth' also made it possible to address the sensitive topic of migration 'through the back door' (International Crisis Group, 2017: 10). The summit deviated from the agenda, however, because on 15 November, CNN broke the news that migrants were being sold off as slaves in Libya (Miyandazi et al., 2018). The news caused an outcry in Africa, and the summit was tasked with finding a solution to the pressing problem of migrants trapped in Libya. The summit did not adopt a new strategic framework, but a Declaration presenting four broad Joint Strategic Priority Areas: Investing in people; Strengthening resilience, peace, security and governance; Mobilizing investments; and Migration and mobility (AU-EU, 2017). The declaration only refers to the AU as object of change. As regards sexual and reproductive health and rights, the Declaration reiterates the commitment to the Maputo Protocol, which concerns the AU, without a similar commitment regarding the EU. The commitments 'to achieving gender equality' and to 'boost joint efforts to advance economic transformation and development, with the objective of creating inclusive and sustainable growth and more and better jobs, especially for youth and women' (AU-EU, 2017: 10) do not apply to the EU, which is striking given the strong mobilization against EU austerity policies (see Kantola and Lombardo, 2017). The declaration does not refer to gender mainstreaming. It takes an 'addingwomen-approach', in the sense that it specifies addressees as 'young people, both girls and boys, as well as women', 'youth and women', 'youth, especially girls and young women', 'youth, especially girls', 'learners, including women and girls', 'young students, staff and researchers, in particular women and girls', 'citizens, especially youth and women and other stakeholders', and 'entrepreneurs . . . including a particular focus on women' (AU-EU, 2017). Nowhere 'men' are explicitly referred to, which implicitly conveys the message that men are the norm and women need special attention to conform to that norm. While the leading AU document on migration contains an entire section on Migration and Gender that starts by saying that 'Who migrates, why, and their migration experience, is affected by gender roles, relations and inequalities' (AU, 2018: 77) and offers a holistic approach to gendered needs and problems of migrant women and men, the Abidjan Declaration only briefly refers to 'the particular vulnerability of women, youth, and children' (AU-EU, 2017: 12), without considering vulnerabilities of men related to gender or sexual orientation.

In sum, gender equality makes fragmented appearances in AU-EU interregional documents and only concerns Africa. In contrast, documents by interregional non-state actors differ in their framing. Interregional CSOs promote gender equality as stand-alone and cross-cutting objective. Interregional youth organizations address not only the AU but also the EU as object of change. Their voices were not included in the Abidjan Declaration.

\section{Conclusion}

Over the years, interregional cooperation between AU and EU has faced several regional and interregional crises. How have gender equality norms fared in this context? We have noticed how interregional documents in many domains, except trade, pay attention to gender equality as stand-alone norm, but lack a cross-cutting approach. They often take an 'adding-women' approach and only address the need for change in Africa. To make sense of this finding, we have proposed a conceptualization of interregional norm 
dynamics as constrained by the logic which shapes the (inter)regional arenas, depending on the mission which drives the organization.

The AU and the EU each have repeatedly expressed their commitment to gender equality and have elaborated it in specific strategies. We have shown how the AU has a state-led developmental logic, which focuses on state-building and people-oriented development. It has developed encompassing, cross-cutting and stand-alone gender equality norms, which resonate with its developmental logic. Its policies also target men. The quality of EU gender equality norms depends on their formulation for 'internal' or 'external' use, which resonates with their different underlying logics. Indeed, the EU has a market-making logic for its 'internal' and trade policies, and a missionary logic for its external relations, except for trade.

In AU-EU interregional relations, no specific strategy concerning gender equality has been developed. Joint documents show fragmented references to gender equality, mainly as stand-alone norm aimed at women as an add-on or specific category. Underlying their interregional relations is a missionary logic, enabling the EU to act as driver and norm entrepreneur. This reproduces the strong power asymmetry and resonates with the EU mission as ethical intervener or normative power. As a result, interregional gender equality norms focus exclusively on Africa as object of change, even though, first, in some respects AU gender equality norms are more encompassing than EU norms; second, gendered effects of crises would merit renewed attention to gender equality in the EU; and third, EU's trade policy has gendered impacts in Africa. Only in documents from interregional youth organizations we did not find this AU-EU asymmetry as they address the need for change in both continents. However, the purely intergovernmental AU-EU arena only gives access to interregional non-state actors during side events, without granting them agenda-setting or monitoring powers. As research on the promotion of gender equality in regional organizations has shown (Galligan, 2017; Roggeband et al., 2014), without bottom-up mobilization and access for feminist actors, gender equality norms remain weak and fragmented, and in times of crisis are easily brushed off the table.

\section{Declaration of conflicting interests}

The author(s) declared no potential conflicts of interest with respect to the research, authorship and/or publication of this article.

\section{Funding}

The author(s) received no financial support for the research, authorship and/or publication of this article.

\section{ORCID iD}

Anna van der Vleuten iD https://orcid.org/0000-0002-1156-9185

\section{References}

Abels G and Mushaben J (eds) (2012) Gendering the European Union: New Approaches to Old Democratic Deficits. London: Palgrave Macmillan.

Acharya A (2016) Regionalism beyond EU-Centrism. In: Börzel T and Risse T (eds) Oxford Handbook on Comparative Regionalism. Oxford: Oxford University Press, pp.109-130.

Adebajo A (2012) Paradise Lost and Found: The African Union and the European Union. In: Adebajo A and Whiteman K (eds) The EU and Africa: From Eurafrique to Afro-Europa. London: Hurst \& Company, pp.45-79. 
Africa-EU Civil Society Forum (2017) Africa-EU Civil Society Forum Declaration. Tunis, 12 July. Available at: https://www.africa-eu-partnership.org/sites/default/files/documents/declaration_tunis_cso_forum_0. pdf (accessed 19 December 2019).

Africa-Europe Youth Summit (2017) The AAbidjan Declaration. In: 4th Africa-Europe Youth Summit, 9-11 October. Available at: https://www.africa-eu-partnership.org/sites/default/files/documents/010-ypiiyouth-agenda-english_bon_leger.pdf (accessed 19 December 2019).

African Union (AU) (2000) Constitutive Act. Available at: https://au.int/en/constitutive-act (accessed 19 December 2019).

African Union (AU) (2003) Protocol to The African Charter on Human and Peoples' Rights on The Rights of Women in Africa. Available at: https://www.un.org/en/africa/osaa/pdf/au/protocol_rights_women africa_2003.pdf (accessed 19 December 2019).

African Union (AU) (2015) Agenda 2063: The Africa We Want. Available at: https://au.int/sites/default/files/ documents/33126-doc-01_background_note.pdf (accessed 19 December 2019).

African Union (AU) (2018) Migration Policy Framework for Africa and Plan of Action 2018-2027. Available at: https:/au.int/en/documents/20181207/migrati.on-policy-framework-africa-mpfa (accessed 19 December 2019).

African Union (AU) (2019) AU Strategy for Gender Equality \& Women's Empowerment 2018-2028. Available at: https://au.int/sites/default/files/documents/36195-doc-au strategy for gender_equality womens_empowerment_2018-2028_report.pdf (accessed 19 December 2019).

African Union (AU) (n.d.) New Partnership For Africa's Development (NEPAD). Available at: https://au.int/fr/ node/3625 (accessed 19 December 2019).

Ahrens P and Van der Vleuten A (2019) Fish Fingers and Measles? Assessing Complex Gender Equality in the Scenarios for the Future of Europe. JCMS: Journal of Common Market Studies 58: 292-308.

Aldiplomasy (2017) Africa: Retreat of the African Union Executive Council to Prepare for the 5th AU-EU Summit, October 18. Available at: http://www.aldiplomasy.com/en/?p=9907 (accessed 19 December 2019).

Allwood G (2019) Gender Equality in European Union Development Policy in Times of Crisis. Political Studies Review. Epub ahead of print 18 July. DOI: 10.1177/1478929919863224.

AU-EU (2007) A Joint Africa-EU Strategy. Available at: https://www.africa-eu-partnership.org//sites/default/ files/documents/eas2007_joint_strategy_en.pdf (assessed 19 December 2019).

AU-EU (2017) Declaration. Investing in Youth for Accelerated Inclusive Growth and Sustainable Development, 30 November 2017. Available at: https:/au.int/en/documents/20171130/investing-youth-acceleratedinclusive-growth-and-sustainable-development (accessed 19 December 2019).

Baert F, Scaramagli T and Söderbaum F (2014) Introduction: Intersecting Interregionalism. In: Baert F, Scaramagli $\mathrm{T}$ and Söderbaum F (eds) Intersecting Interregionalism: Regions, Global Governance and the $E U$. Dordrecht: Springer, pp.1-12.

Banda F (2005) Women, Law and Human Rights: An African Perspective. Portland, OR: Hart Publishing.

Bloomfield A (2016) Norm Antipreneurs and Theorising Resistance to Normative Change. Review of International Studies 42 (2): 310-333.

Council (2015a) Valletta Summit, 11-12 November 2015 Political Declaration. Available at: https://www. consilium.europa.eu/media/21841/political_decl_en.pdf (accessed 27 April 2020).

Council (2015b) Valletta Summit, 11-12 November 2015 Action Plan. Available at: https://www.consilium. europa.eu/media/21839/action_plan_en.pdf(accessed 27 April 2020).

Council (2017) Council Conclusions on a Renewed Impetus for the Africa-EU Partnership. Available at: https:// www.consilium.europa.eu/media/23994/st10454en17-conclusions-on-a-renewed-impetus-for-the-africa-eu-partnership.pdf (accessed 19 December 2019).

Damro C (2012) Market Power Europe. Journal of European Public Policy 19 (5): 682-699.

De Melo J (2017) A Fresh Look at Africa's Integration in Regional Economic Communities. Bridges Africa 6 (7): 1-6.

Debusscher P and Van der Vleuten A (2017) Equality Policies in the EU through a Feminist Historical Institutionalist Lens. In: MacRae H and Weiner E (eds) Towards Gendering Institutionalism. Equality in Europe. London: Rowman \& Littlefield, pp.3-24.

European Commission (2015a) Joint Staff Working Document. Gender Equality and Women's Empowerment: Transforming the Lives of Girls and Women through EU External Relations 2016-2020 (GAP II). Available at: https://ec.europa.eu/anti-trafficking/sites/antitrafficking/files/joint_staff_working_document_-_gender_equality_and_womens_empowerment.pdf (accessed 19 December 2019). 
European Commission (2015b) Strategic Engagement for Gender Equality 2016-2019. Available at: https:// ec.europa.eu/anti-trafficking/eu-policy/strategic-engagement-gender-equality-2016-2019_en (accessed 19 December 2019).

European Commission (2017a) Joint Communication to the European Parliament and the Council for a Renewed Impetus of the Africa-EU Partnership. Available at: https://eur-lex.europa.eu/legal-content/EN/TXT/PDF /?uri=JOIN:2017:17:FIN\&from=ENEU (accessed 19 December 2019).

European Commission (2017b) Joint Staff Working Document. Assessing the Africa-EU Partnership - Key Findings from Evaluations. Available at: https:/eur-lex.europa.eu/legal-content/lt/ TXT/?uri=CELEX:52017SC0150 (accessed 19 December 2019).

European Commission (2017c) Joint Staff Working Document. Consultations and Stakeholders' Views. Available at: https://eur-lex.europa.eu/legal-content/EN/TXT/PDF/?uri=CELEX:52017SC0151\&from $=$ EN (accessed 19 December 2019).

European Commission (2017d) White Paper on the Future of Europe - Reflections and Scenarios for the EU27 by 2025. Available at: https://ec.europa.eu/commission/sites/beta-political/files/white_paper_on_the_ future_of_europe_en.pdf (accessed 19 December 2019).

European External Action Service (EEAS) (2016) Shared Vision, Common Action: A Stronger Europe. The Global Strategy for the European Union's Foreign and Security Policy. Available at: https://eeas.europa. eu/topics/eu-global-strategy/17304/global-strategy-european-unions-foreign-and-security-policy_en (accessed 19 December 2019).

European Parliament (2017) The Joint Africa-EU Strategy. Available at: http://www.europarl.europa.eu/ RegData/etudes/STUD/2017/603849/EXPO_STU(2017)603849_EN.pdf (accessed 19 December 2019).

Galligan Y (2017) Filtering Out, Filtering In: What Place for Gender in European Economic Plans? In: MacRae $\mathrm{H}$ and Weiner E (eds) Towards Gendering Institutionalism: Equality in Europe. London: Rowman \& Littlefield, pp.25-42.

Hall P (1993) Policy Paradigms, Social Learning, and the State: The Case of Economic Policymaking in Britain. Comparative Politics 25 (3): 275-296.

Hänggi H (2006) Interregionalism as a Multifaceted Phenomenon: In Search of a Typology. In: Hänggi H, Roloff R and Rüland J (eds) Interregionalism and International Relations. London: Routledge, pp.31-62.

Hardacre A and Smith M (2014) The European Union and the Contradictions of Complex Interregionalism. In: Baert F, Scaramagli T and Söderbaum F (eds) Intersecting Interregionalism: Regions, Global Governance and the EU. Dordrecht: Springer, pp.91-106.

International Crisis Group (2017) Time to Reset African Union-European Union Relations (Africa Report No. 255). Available at: https://www.crisisgroup.org/africa/255-time-reset-african-union-european-union-relations (accessed 19 December 2019).

Jacquot S (2015) Transformations in EU Gender Equality: From Emergence to Dismantling. Basingstoke: Palgrave Macmillan.

Kantola J and Lombardo E (eds) (2017) Gender and the Economic Crisis in Europe: Politics, Institutions and Intersectionality. Basingstoke: Palgrave Macmillan.

Kotsopolous J and Mattheis F (2018) A Contextualisation of EU-Africa Relations: Trends and Drivers from a Reciprocal Perspective. South African Journal of International Affairs 25 (4): 445-460.

Lavenex S and Schimmelfennig F (2009) EU Rules beyond EU Borders: Theorizing External Governance in European Politics. Journal of European Public Policy 16 (6): 791-812.

Lieshout RH (1999) The Struggle for the Organization of Europe: The Foundations of the European Union. London: Edward Elgar.

Miyandazi L, Apiko P, Abderrahim T, et al. (2018) AU-EU Relations: Challenges in Forging and Implementing a Joint Agenda. South African Journal of International Affairs 25 (4): 461-480.

Ribeiro Hoffmann A (2016) Inter- and Transregionalism. In: Börzel TA and Risse T (eds) The Oxford Handbook of Comparative Regionalism. Oxford: Oxford University Press, pp.600-618.

Risse T (2016) The Diffusion of Regionalism. In: Börzel TA and Risse T (eds) The Oxford Handbook of Comparative Regionalism. Oxford: Oxford University Press, pp.87-108.

Roggeband C, van Eerdewijk A and van der Vleuten A (2014) Reconceptualizing Gender Equality Norm Diffusion and Regional Governance: Logics and Geometries. In: Van der Vleuten A, Van Eerdewijk A and Roggeband C (eds) Gender Equality Norms in Regional Governance: Transnational Dynamics in Europe, South America and Southern Africa. London: Palgrave Macmillan, pp.221-246.

Rutazibwa OU (2010) The Problematics of the EU's Ethical (Self)Image in Africa: The EU as an 'Ethical Intervener' and the 2007 Joint Africa-EU Strategy. Journal of Contemporary European Studies 18 (2): 209-228. 
Söderbaum F (2016) Old, New, and Comparative Regionalism: The History and Scholarly Development of the Field. In: Börzel T and Risse T (eds) Oxford Handbook on Comparative Regionalism. Oxford: Oxford University Press, pp.16-37.

Treaty of Amsterdam (1997) Consolidated Version of the Treaty Establishing the European Community. Official Journal of the European Communities C 340/173.

Van der Vleuten A (2016) Regional Social and Gender Governance. In: Börzel T and Risse T (eds) Oxford Handbook on Comparative Regionalism. Oxford: Oxford University Press, pp.406-429.

Van der Vleuten A and Ribeiro Hoffmann A (2013) Chapter 32: The Politics of Regionalism: Relations between International Regional Organizations. In: Reinalda B (ed.) Routledge Handbook on International Organization. London: Routledge, pp.430-444.

Van Eerdewijk A and Lodenstein E (2018) The State of African Women Report. Available at: https://www.kit. nl/project/state-of-african-women-report/ (accessed 19 December 2019).

Walby S (2018) Gender in the Crisis and Remaking of Europe: Re-gendering Subsidiarity. European Journal of Politics and Gender 1 (3): 307-324.

Welfens N (2019) Protecting Refugees Inside, Protecting Borders Abroad? Gender in the EU's Responses to the 'Refugee Crisis'. Political Studies Review. Epub ahead of print 19 December. DOI: $10.1177 / 1478929919887349$.

\section{Author Biographies}

Anna van der Vleuten is professor of Contesting Europeanization at the Institute for Management Research, Radboud University, Nijmegen, The Netherlands. Her research interests include the intersection of comparative regionalism, EU and gender studies. Her current projects focus on gender in EU external relations with African regional organizations, and contestations of transgender rights and categories of sex.

Anouka van Eerdewijk is senior adviser at the Department Sustainable Economic Development and Gender of the Royal Tropical Institute, Amsterdam, and affiliated researcher at Institute for Management Research, Radboud University Nijmegen. She combines research, activism and advisory work in international development, with an explicit focus on women's empowerment, rights and leadership. She coordinated the research and was key author of the State of African Women report for the Right By Her campaign (2019). 